\title{
静的安定性と剛性可変機能を有する 拮抗駆動型ロボット関節機構
}

\author{
山口懐*1 竹 節 淑 敏*2 玉 本 拓 巳*3 小金澤 鋼 一*4

\section{An Antagonistic Mechanism of Robot Joint with Static Stability and Stiffness Adjustability}

\author{
Natsuki Yamaguchi*1, Yoshitoshi Takefushi*2 ${ }^{*}$ Takumi Tamamoto*3 and Koichi Koganezawa*4
}

\begin{abstract}
Some research institutions have developed biped-walking robots aimed for prospective cooperative working with humans. Among various research items related to them, waist joint is important because it gives so much influence to the stability of upper body. Many biped-walking robots developed so far use a single rotary joint in waist joint, but it has a crucial drawback in energy consumption to stabilize the upper body. In our research a new mechanism has proposed, which consists of a crossover 4-bar linkage controlled by two motors via springs. The crossover 4-bar linkage is intrinsically more stable than a single rotary joint. Two springs are arranged counteractively to regulate the stiffness of the waist joint. This paper shows a stability index to evaluate stability of the crossover 4-bar linkages. It also proposes a mechanism of the waist joint followed by examinations of allocation of the linkages and springs in terms of stiffness control. We developed a test machine based on the simulation results and achieved some experiments, which clearly showed the experimental results are well coincident with the theoretical one.
\end{abstract}

Key Words: Biped Walking Robot, Waist Joint, Joint Stiffness Adjustment

\section{1. 序論}

近年，様々なロボットの研究が盛んに行われている．人間の 生活環境の中で人間と共存する目的のものから，人の手による 作業が難しい極限環境の中で作業することを目的としているロ ボットなど数多くのロボットが開発されている. ロボットの移 動手段としても様々な方法があるが 2 足歩行は, その形状から 人間の環境で有効に活動することのできるロボットの移動手段 だと考えられる。

2 足歩行ロボットの研究は主に能動歩行ロボットと受動歩行ロ ボットに大別することができる，能動歩行ロボットは現在行わ れている 2 足歩行ロボットの研究の中でも広く研究が行われて いる分野であり，関節ごとに配置されたアクチュエータを常に 制御し続け駆動させることで歩行している。代表的なものとし て, ASIMO (本田技研工業株式会社) [1] や Nao（Aldebaran

原稿受付 2015 年 4 月 27 日

$* 1$ 太陽工業株式会社物流システムカンパニー

$* 2$ 沖電気工業株式会社

$* 3$ 東海大学大学院総合理工学研究科

$* 4$ 東海大学工学部機械工学科

${ }^{* 1}$ Taiyo Kogyo Corporation

${ }^{* 2}$ Oki Electric Industry Co., Ltd

${ }^{* 3}$ Graduate School of Science and Technology, Tokai University

${ }^{* 4}$ Dep. of Mechanical Engineering, Tokai University

口本論文は有用性（要素分野）で評価されました。
Robotics 社）などがこれに分類される.

受動歩行ロボットはアクチュエータを基本的に用いずに，ポテ ンシャルエネルギー, 慣性力, 遠心力, コリオリカを利用して下 肢のサイクリックな歩行運動を生成する試みであり, McGeer [2] による研究を嗃矢とし，様々な研究がこれまで行われている [3]〜 [6]. 受動歩行はエネルギー効率が非常に高く，人間の下肢の歩 行運動に近い歩容が得られることが知られている [3]. しかしな がら，歩容の安定性や，様々な歩行条件（歩行速度，歩行面の 形状等）に柔軟に対応させるためには受動関節に能動的駆動を 若干加える必要がある [4]. さらに，上体を付加することが，歩 行の効率性に寄与するとの報告がある [5]. 受動歩行ロボットは 坂道で歩行可能であることが知られているが，その坂道の歩行 において上体を取り付けたことにより低角度での坂道歩行が可 能になり移動効率が向上している $[6]$. 受動歩行ロボットに上体 を付加する場合，上体の姿勢を常に安定させる制御が必要とな り，必然的にアクチュエータを上体に搭載し，基本的に受動で 動作する腰関節に能動駆動を付加することが必要となる．また， 受動運動を行う場合においても，上体の慣性力などの外力に対 する腰関節の受動動作の制御，すなわち，関節剛性を歩行周期

の諸局面において調節する必要がある。

本研究では受動歩行ロボットをベースとし，これに能動的駆 動要素を付加し, 関節剛性を可変するための機構の提案を行っ てきた $[7]$. 先行研究においては能動駆動と受動駆動を融合させ 
る機械要素として遊星歯車を用い [8], これを交叉型 4 リンク機 構（Crossover Four-Bar Linkage; CFBL）と組み合わせた関 節機構を提案した [7]. 遊星歯車を用いる場合, 能動駆動入力と 剛性制御入力を峻別できるため, 制御の簡便さという点では有 利である。しかしながら，次章で述べる CFBL へのトランス ミッションとして用いる場合, アクチュエータからの動力伝達 の経路にいくつかの歯車を用いる必要があり，伝達ロスとバッ クラッシの影響が懸念される.

そこで，本論で提案する新たな関節機構においては，CFBL をバネを介して二つのモータで駆動する拮抗駆動方式を用いる. 拮抗駆動であるため，二つのモータがもつ役割には区別がなく， 基本的にそれらの同相駆動で関節剛性が制御され，異相駆動で 関節角度が制御される。

本論は以下の構成となっている，次章において機構の概要を 示した後，第 3 章において CFBL を用いる理由とその設計に ついて機構的安定性インデックスを用いて説明する. 第 4 章は, CFBL をバネを介して拮抗駆動する際のバネの配置を, 関節剛 性の制御性の観点から検討する。第 5 章では，第 3,4 章で設 計した拮抗駆動方式をとる CFBL の挙動について動力学解析に より検証する．第 6 章では，製作した実機を用いて関節剛性が 理論どおり調節可能かについての検証と, ステップ応答の挙動 についての検証を示す。第 7 章は結言である.

\section{2. 機 構 概 要}

Fig. 1 に本論で提案する関節機構の構成を $3 \mathrm{D}$ モデルで示す. 第 6 章に示すように，Fig. 1 に示したものとほぼ同じ実機が製 作されている。この機構の最大の特徴は CFBL を有している点 である. 4 リンク機構は 1 自由度であり, その回転中心は交叉 型の場合，傾斜する 2 本のリンクの交叉点である. 上体に 2 基 のモータを平行に配置している。モモタに取り付けられたプー リにワイヤを固定し，そのワイヤを通じて引張バネを取り付け， モータを回転させワイヤを巻き取ることでバネが伸縮する. バ ネの下端は傾斜するリンクに接続している.この機構を元に, 静 力学解析から各パラメータを決定し, 動力学解析を行い, 解析 に基づいて実験機を製作し直立安定実験と剛性実験を行った。

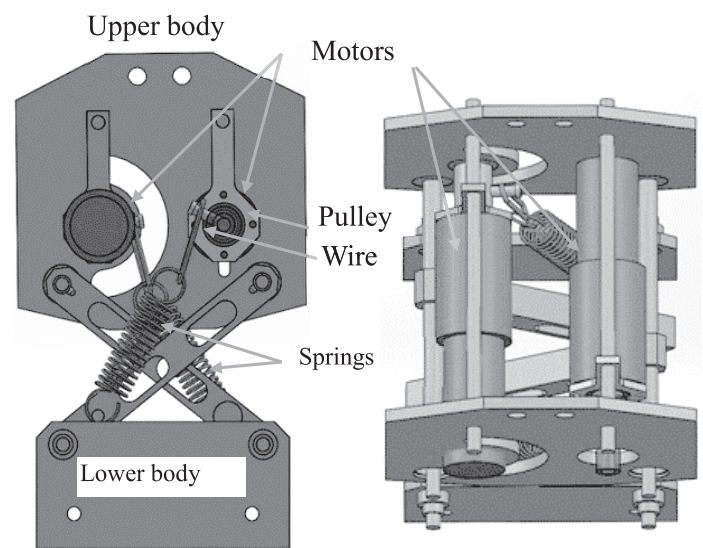

Fig. 1 Assembly of the proposed joint mechanism

\section{CFBL}

\subsection{CFBL の概要}

一般的な人型ロボットの関節機構は一軸回転構造であり，高 減速比の減速機を介して一つのモータとダイレクトに接続され ている．利点としては構造がシンプルな点が挙げられるが，関 節剛性が基本的に高く，外力に対する柔軟な挙動を行うために はセンサリフィードバックを用いたインピーダンス制御が必要 である。それに対し本論では CFBL を採用する。 CFBL は古 くより大腿義足の膝関節などに用いられてきた機構であり [9], 姿勢保持の安定性が機構的に備わっていることが知られている. また，交叉型を用いる理由は関節の可動角が広いことにある.

Fig. 2 にCFBL を用いた関節の回転の状況を示す。回転中心 が移動するため上体と下体の接触を広い角度範囲で避けること ができる。

\section{2 機構学的安定性インデックス}

CFBL の機構的な安定性を測る指標として式（1）に示す機 構学的安定性インデックス (Mechanical Stability Index; $I_{s m}$ ) が提案されている [7]. Fig. 3 は各パラメータの説明である.こ れは CFBL を腰関節に用いた場合の直立静止状態を想定してい る. $\mathrm{CFBL}$ は傾くとき, 回転中心 $p_{C}$ が矢印方向に移動し, 上 体質量の重力ベクトルに対するモーメントアームが $p_{w x}-p_{c x}$ となり， $p_{w x}$ よりも小さくなり，回転中心に作用するトルクが 小さくなるため安定性が増すと考えている.

式（1）で定義する $I_{s m}$ は，4 リンク機構における角度 $\theta_{w}$ の

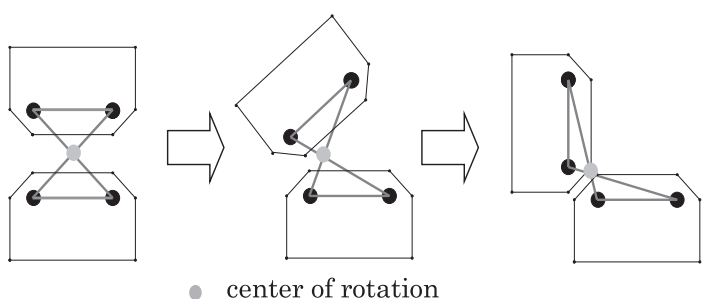

Fig. 2 Rotation of the CFBL

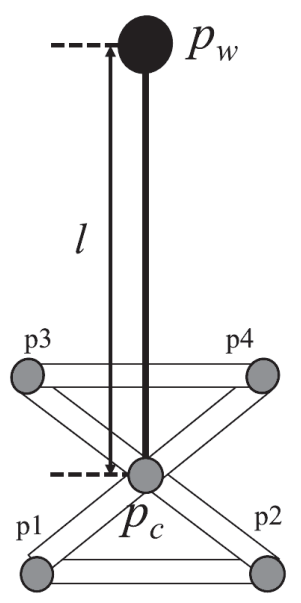

Upright state

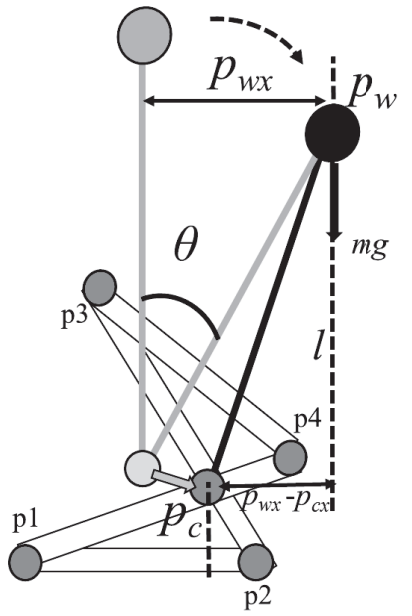

Anteflexion state
Fig. 3 The definition of $I_{s m}$ 


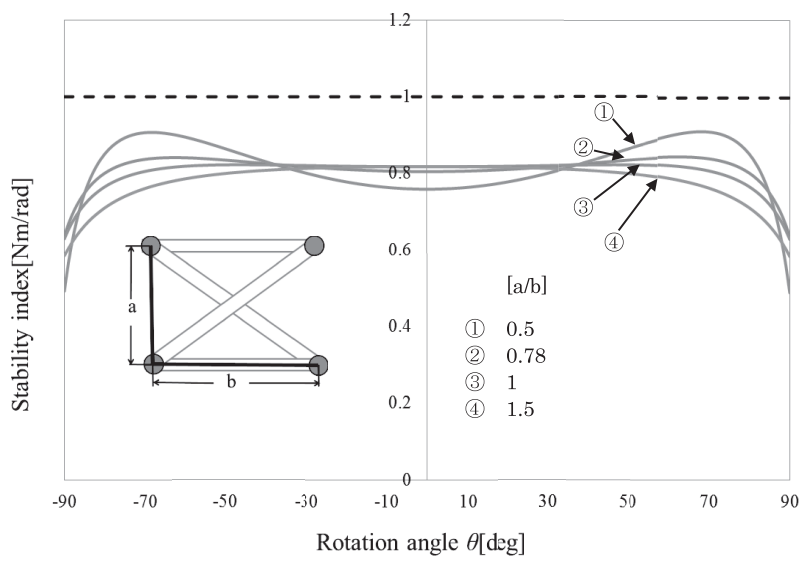

Fig. 4 Stability index in various form of the CFBL

変化に対する機構より上の質量中心 $p_{w}$ と 4 リンクの回転中心 $p_{c}$ との差の $\mathrm{x}$ 成分と質量中心 $p_{w}$ の $\mathrm{x}$ 成分率の比である. これ は小さいほど安定性を有していることを示している。一軸回転 構造の関節においては $I_{s m}$ は関節角度にかかわらず常に 1 で ある。

$$
I_{s m}=\frac{d\left(p_{w x}-p_{c x}\right) / d \theta_{w}}{d\left(p_{w x}\right) / d \theta_{w}}
$$

\section{3 CFBL の形状の違いによる $I_{s m}$ の違い}

Fig. 4 は一軸回転構造と Fig. 3 のモデル図の a と b の比を 変化させた際の安定性インデックスである. 横軸は回転中心角 $\theta_{w}$, 縦軸は安定性インデックスとなっており, 安定性インデッ クスが小さいほど安定性を有していることを示している. Fig. 4 より CFBL の $I_{s m}$ はどの関節角においても 1.0 を下回ってお り一軸回転構造の関節よりも安定であることを示している.さ らに姿勢保持という観点から最も重要な関節角 $0[\mathrm{deg}]$ 付近にお いて $I_{s m}$ に違いが見られることが分かる. CFBL の形状が横長 であるほど関節角 $0[\mathrm{deg}]$ 付近において $I_{s m}$ が小さな值となり， 安定性に優れているという結果を得た。この結果より 4 リンク 機構の形状としては横長であるほど安定性の上では望ましいが, 過度に横長形状にすると関節角稼働域が十分に取れないという 問題点が生ずるため, 以下の解析ならびに，実機の製作におい ては $a / b=0.78 （ a=70[\mathrm{~mm}], b=90[\mathrm{~mm}])$ を採用した.

\section{4. 関節剛性の解析}

\section{1 解析手法}

より高い剛性值と広い剛性調節域を得るためのバネ取付位置 とモー夕設置位置を決定するため静力学的解析を行った. 本論 で提案する関節機構は拮抗配置された二つのバネにより剛性を 変化させる機構であるため, 式 (2) の左辺に示される上体に関 するポテンシャルエネルギーが, 右辺のバネ 1 とバネ 2 に関す るポテンシャルエネルギーを足した值と等しくなる.

$$
\frac{1}{2} S_{w} \theta_{w}^{2}=\frac{1}{2} k_{s}\left(x_{1}^{2}+x_{2}^{2}\right)
$$

ここで， $\theta_{w}$ は上体の下体に対する回転角度であり， $S_{w}$ はその 回転に関する回転剛性 $[\mathrm{Nm} / \mathrm{rad}]$ である． $k_{s}$ はバネ定数 $[\mathrm{N} / \mathrm{m}]$ であり二つのバネが同じばね定数をもっていると想定している.

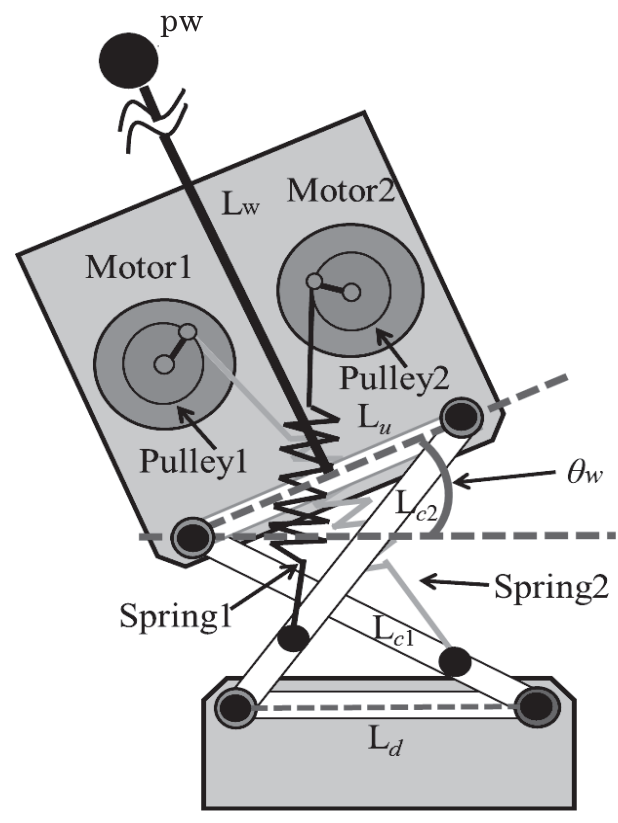

Fig. 5 Kinetic analysis model for the joint stiffness

$x_{1}, x_{2}$ はバネの変位長さ $[\mathrm{m}]$ であり, バネの取付位置によって 変化する関節角度 $\theta_{w}$ の非線形関数である. 式 $(2)$ を $\theta_{w}=0$ およびその近傍において $S_{w}$ が $\theta_{w}$ に関して 2 回まで微分可能 であると仮定し， $\theta_{w}$ に関して 2 回微分し式 (3) を得る.

$$
\begin{aligned}
S_{w}=k_{s} & ( \\
+ & \left.\frac{d x_{1}}{d \theta_{w}}\right)^{2}+x_{1}\left(\frac{d^{2} x_{1}}{d \theta_{w}^{2}}\right) \\
& \left.+\left(\frac{d x_{2}}{d \theta_{w}}\right)^{2}+x_{2}\left(\frac{d^{2} x_{2}}{d \theta_{w}^{2}}\right)\right)\left.\right|_{\theta_{w} \rightarrow 0}
\end{aligned}
$$

式 $(3)$ は関節角度 $\theta_{w}=0$ のときの関節剛性を計算する式であ る. 上記の仮定は以下の 2 点を意味している.

$\theta_{w}=0$ 付近においてCFBL が特異姿勢（隣接リンクが平行 姿勢になる状態）にならないこと，またバネの使用制限を超え た伸張・圧縮が生じないことである.

Fig. 5 は解析モデルである. 4 リンク機構形状は縦 $70[\mathrm{~mm}]$, 横 $90[\mathrm{~mm}]$ に設定し，バネ定数は両者同じく $13.35[\mathrm{~N} / \mathrm{mm}]$, プーリの半径は $8[\mathrm{~mm}]$ に設定した.

バネの上端はワイヤをモータに取り付けたプーリに巻き付け ることにより牽引される．牽引量が小さい場合，Fig.6 (a) に 示すようにワイヤがプーリの接線方向ではない方向に向くよう に設定されている，このように設定することにより，次節の解 析結果で示されるように，バネの牽引量が小さいときにより低 い関節剛性を実現でき，関節剛性の調節範囲が広がる.

\section{2 バネ取付位置を変化させた場合の剛性の違い}

まずバネ取付位置を変化させた際の剛性值を算出した. Fig. 7 に解析条件を示す，モー夕配置位置を示す L2, L3 をそれぞれ $30[\mathrm{~mm}], 25[\mathrm{~mm}]$ に設定した. バネのリンクへの取付位置につ いては，p1，p2 を起点とした L1 の長さを $0[\mathrm{~mm}], 30[\mathrm{~mm}]$, $60[\mathrm{~mm}]$ と変化させ式（3）の計算を行った. Fig. 8 に結果を 示す。横軸はバネの伸び長さであり二つのバネを同じ長さだけ 伸ばすことを想定している. Fig. 8 から分かるとおり，L1 が 


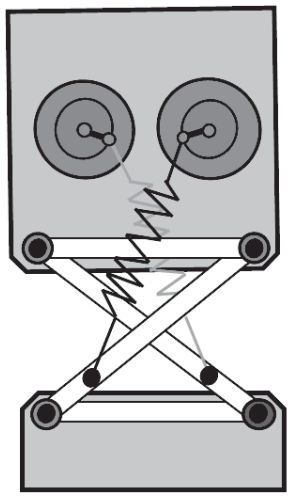

(a) Low stretching

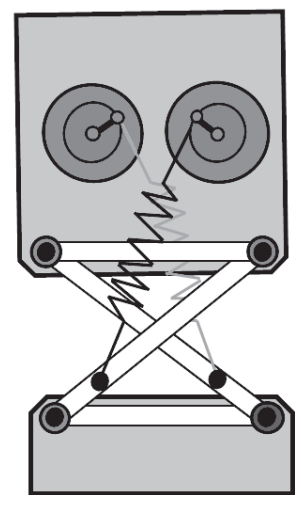

(b) High stretching
Fig. 6 Spring traction by motor and pulley
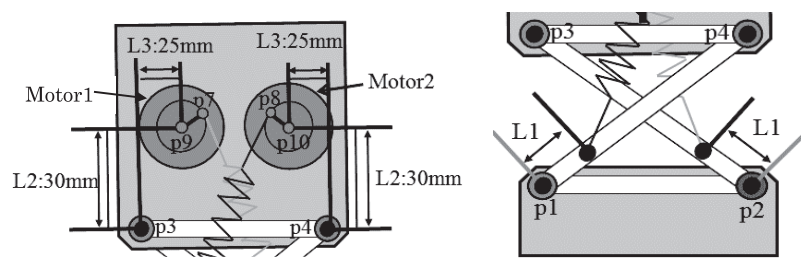

Fig. 7 Motor location and connecting point of the springs

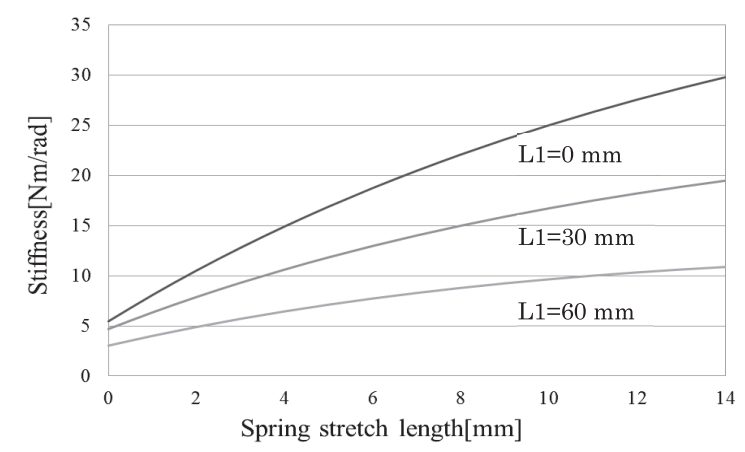

Fig. 8 Difference of stiffness change according to the spring connecting point $\mathrm{L} 1$

$60[\mathrm{~mm}]$ の場合に剛性值が最も小さくなり最低剛性值と最高剛 性值の幅が狭かったのに対し，L1 が $0[\mathrm{~mm}]$ の場合に剛性值が 最も大きくなり, かつ最低剛性值と最高剛性值の差が大きくな るという結果が得られた。この結果から, L1 が短いほど剛性值 ならびに剛性調節範囲が大きくなることが分かった.

\section{3 モータの垂直位置を変化させた場合の剛性の違い}

次にモータの配置を上下に変化させた場合の剛性值を算出し た。解析条件はバネ拘束位置 L1 を最下端である $0[\mathrm{~mm}]$ とし， Fig.9(a)のようにL3を $25[\mathrm{~mm}]$ に設定し，p3，p4を起点と して高さ L2 $210[\mathrm{~mm}], 20[\mathrm{~mm}], 30[\mathrm{~mm}], 40[\mathrm{~mm}]$ と変化 させて剛性値を算出した。 その結果を Fig. 10 に示す. L2 が $40[\mathrm{~mm}]$ の場合に剛性值ならびに剛性可変範囲が最も大きくなっ たのに対し，10[mm] の場合にそれらが最も小さくなった。 こ の結果から L2 が長いほど剛性值ならびに剛性調節範囲が大き くなるという結果が得られた。

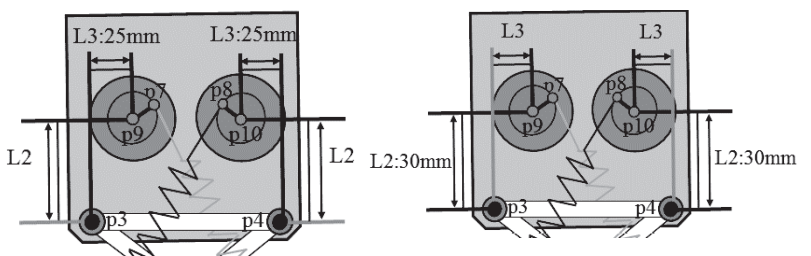

(a) The case of changing L2

(b) The case of changing L3

Fig. 9 Motor Location

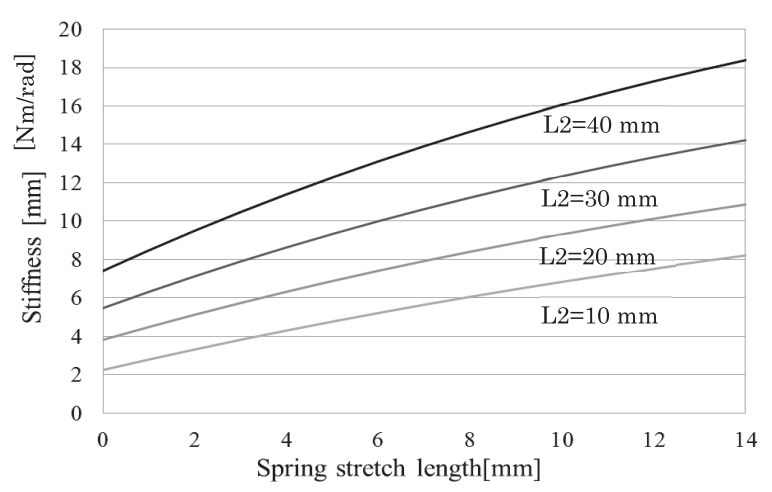

Fig. 10 Difference of stiffness change according to the motors' vertical location L2

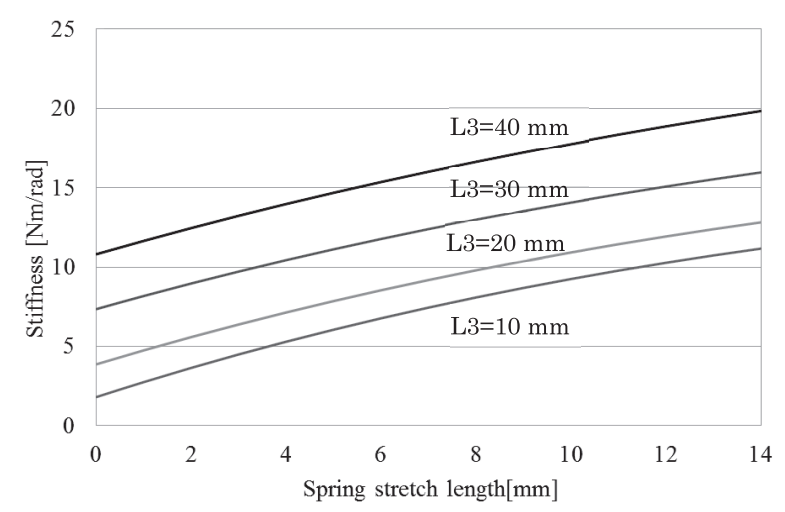

Fig. 11 Difference of stiffness change according to the motors' horizontal location L3

\section{4 モータの水平位置を変化させた場合の剛性の違い}

次にモータの配置を左右に変化させた際の剛性值を算出し た．解析条件はバネ拘束位置 L1 を最下端である $0[\mathrm{~mm}]$ とし， Fig. 9 (b)のようにL2 を $30[\mathrm{~mm}]$ に設定し，p3，p4 を起点と して水平距離 L3 を $10[\mathrm{~mm}], 20[\mathrm{~mm}], 30[\mathrm{~mm}], 40[\mathrm{~mm}]$ と 変化させて剛性值を算出した，その結果，Fig. 11 から分かると 㧍り L3 が $10[\mathrm{~mm}]$ の場合に剛性值が全体として最も低くなっ たのに対し，40[mm] の場合に剛性值が最も高くなった。この 結果から L3 が長いほど剛性値が高くなるという結果が得られ た。剛性調節範囲に関しては L3 を変えたことによる顕著な違 いが見られなかった。

\section{5 モータ配置ならびにバネ取付位置の設定}

以上の解析結果を元にモー夕配置ならびにバネ取付位置を決定 した．１1は p1，p2に近いほど剛性調節範囲が広いため $0[\mathrm{~mm}]$ に設定した，L2 は $35[\mathrm{~mm}]$ に設定した。理由としては，L2 は 長いほど剛性值は高まるが，本機構は人体を模した設計となっ 


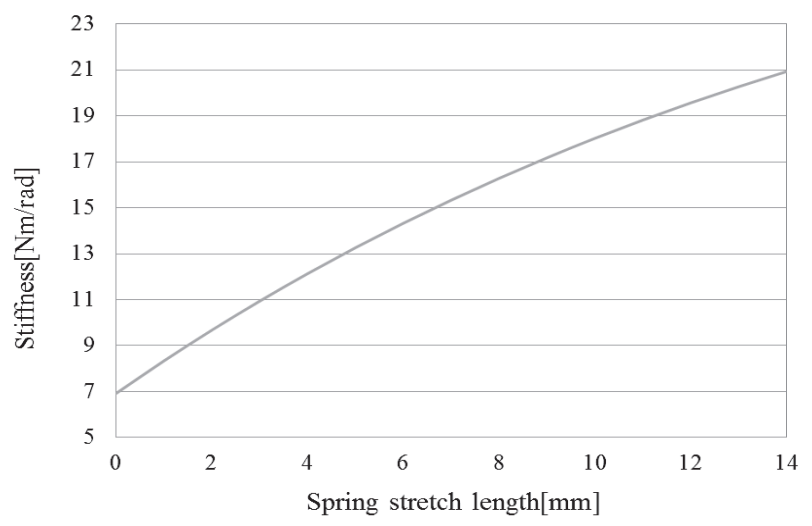

Fig. 12 Stiffness change in the determined motor-spring allocation

ているため，コンパクトにできる限界の高さを設定したＬL3 は長いほど剛性值は高くなるが，モー夕同士が接触しないよう に $27[\mathrm{~mm}]$ に設定した．以上の設定により得られる剛性変化を

Fig. 12 に示す. バネの伸び長さゼロにおいても，7 [ $\mathrm{Nm} / \mathrm{rad}]$ の回転剛性を有しており, バネを $14[\mathrm{~mm}]$ 伸ばした場合，その約 3 倍の剛性值が得られる. 以上の設定值を用いて動力学解析を行 い，また実機を製作して直立安定実験，剛性調節実験を行った。

\section{5. 動 力 学解 析}

\section{1 解析手法}

Fig. 13 に動力学解析モデルを示す. 2 基のモー夕位置は前 章の静力学解析によって決定した位置とする.プーリーの半 径は $8[\mathrm{~mm}]$ である. バネのリンクへの接続位置は前章の解析 結果に従い 4 リンクの関節 $\mathrm{p} 1$ と $\mathrm{p} 2$ に接続し, リンク長は $L_{d}=L_{u}=90[\mathrm{~mm}], L_{c 1}=L_{c 2}=114[\mathrm{~mm}]$ とする. 上体に は上方 $L_{w}=300[\mathrm{~mm}]$ の位置に $1[\mathrm{~kg}]$ の集中質量が存在する とし, モータやリンク質量, それらの慣性モーメントも考慮し ている. バネ定数は $40.5[\mathrm{~N} / \mathrm{mm}]$ とした.

解析はラグランジュの運動方程式を用いて行った. 式 (4) の $L$ はラグランジアンであり, $L^{\prime}$ は $L$ に拘束式ベクトル $\boldsymbol{\Phi}$ とラ グランジュの未定係数ベクトル $\boldsymbol{\lambda}$ の内積で計算される拘束エネ ルギーを加えた拡張ラグランジアンである. 式 (4) をラグラン ジュの運動方程式（5）に代入する. 式（5）の q は一般化座標 であり, Fig. 13 の 4 リンクの角度 $\alpha, \beta, \gamma$ を要素とするべク トルである.

$$
\begin{gathered}
L^{\prime}=L+\boldsymbol{\Phi}^{\mathbf{T}} \boldsymbol{\lambda} \\
\mathbf{d}\left(\partial L^{\prime} / \partial \dot{\mathbf{q}}\right) / \mathbf{d} \mathbf{t}-\partial L^{\prime} / \partial \mathbf{q}=\mathbf{Q}_{\mathbf{e x}}
\end{gathered}
$$

本機構は平面 4 リンク機構であるため, 式（6）に示す関節 p2 に関する二つのホロノミック拘束式を立てることができる.

$$
\mathbf{\Phi}=\left[\begin{array}{l}
L_{\mathrm{c} 2} \cos \alpha-L_{\mathrm{d}}-L_{\mathrm{c} 1} \cos \beta-L_{\mathrm{u}} \cos \theta_{w} \\
L_{\mathrm{c} 2} \sin \alpha-L_{\mathrm{c} 1} \sin \beta-L_{\mathrm{u}} \sin \theta_{w}
\end{array}\right]
$$

式（6）を二階微分し，拘束安定性を高めるためにBaumgarte の安定化式（7）を内装することにより式（8）が得られる。こ こで, $\boldsymbol{\Phi}_{\mathbf{q}}=\partial \boldsymbol{\Phi} / \partial \mathbf{q}, \mathbf{\Phi}_{t}=\partial \boldsymbol{\Phi} / \partial t$ である. $\omega_{1}, \omega_{2}$ は Baumgarte 係数であり，両者を 100 に設定した. $\omega_{1}, \omega_{2}$ の值を小さ

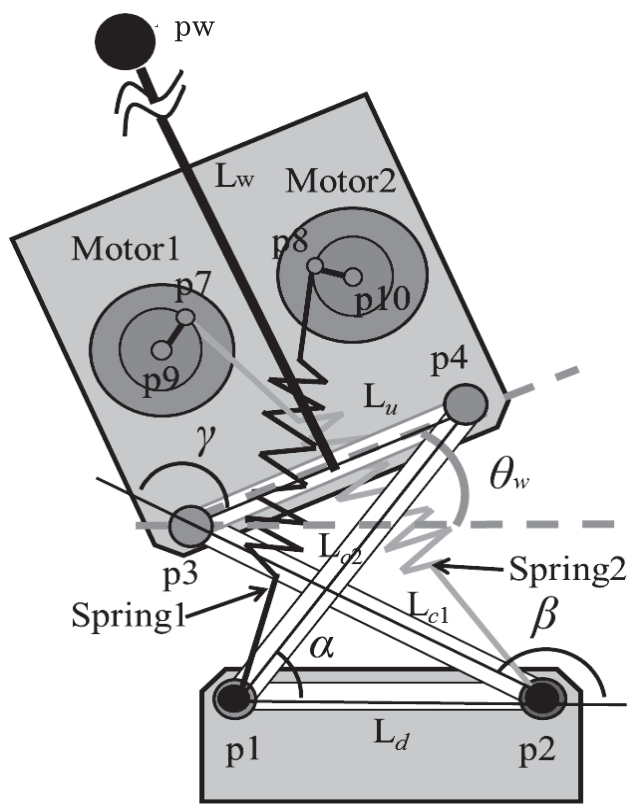

Fig. 13 Dynamic analysis model of the joint

くすると拘束力が弱くなり, 大きくすると拘束力が強すぎ, 数 值積分がしばしば発散するため, 試行錯誤で設定した. 式 (5) と式（7）を混合微分代数方程式（9）にまとめ，これをルンゲ. クッタギル法を用いて時間刻み $1[\mathrm{~ms}]$ で数值積分を行った. 式 （9）における $\mathbf{M}$ は慣性項行列である.

$$
\begin{gathered}
\ddot{\mathbf{\Phi}}+2 \omega_{1} \dot{\boldsymbol{\Phi}}+\omega_{2}^{2} \boldsymbol{\Phi}=0 \\
\boldsymbol{\Phi}_{\mathbf{q}} \ddot{\mathbf{q}}=-\dot{\boldsymbol{\Phi}}_{\mathbf{q}} \dot{\mathbf{q}}-\dot{\boldsymbol{\Phi}}_{t}-2 \omega_{1}\left(\boldsymbol{\Phi}_{\mathbf{q}} \dot{\mathbf{q}}+\boldsymbol{\Phi}_{t}\right)-\omega_{2}^{2} \boldsymbol{\Phi} \\
\left(\begin{array}{cc}
\mathbf{M} & -\boldsymbol{\Phi}_{\mathbf{q}}^{\mathbf{T}} \\
\boldsymbol{\Phi}_{\mathbf{q}} & 0
\end{array}\right)\left(\begin{array}{c}
\ddot{\mathbf{q}} \\
\boldsymbol{\lambda}
\end{array}\right)= \\
\left(\begin{array}{c}
\mathbf{Q}_{\mathbf{e x}}+L_{\mathrm{q}}-\dot{\mathbf{M}} \dot{\mathbf{q}} \\
-\dot{\boldsymbol{\Phi}}_{\mathbf{q}} \dot{\mathbf{q}}-\dot{\boldsymbol{\Phi}}_{t}-2 \omega_{1}\left(\boldsymbol{\Phi}_{\mathbf{q}} \dot{\mathbf{q}}+\boldsymbol{\Phi}_{t}\right)-\omega_{2}^{2} \mathbf{\Phi}
\end{array}\right)
\end{gathered}
$$

\section{2 直立安定性解析}

5.1 節に示した式に基づいて直立安定性解析を行った.

直立姿勢（上体の集中質量の位置 $p_{w}$ に向かう線 $L_{w}$ が垂直 状態の姿勢）から上体を右方向へ傾け，関節角度が $-40[\mathrm{deg}]$ の 状態から運動が開始されたと想定して動力学解析を行った.上 体を大きく傾けた状態から始める理由は, 重力の影響により関 節角度がゼロに収束しない可能性が考えられるからである. 関 節 $\mathrm{p} 1$ にロータリーダンパが設置されていると想定し振動减衰さ せ, Fig. 13 の関節角度 $\theta_{w}$ の角度变化を計算した。解析は二つ のバネの引張長さを $0[\mathrm{~mm}]$ に設定した場合と，5[mm]に設定 した場合について行った．解析結果を Fig. 14 に示す.この結 果から分かると抢り，両者ともに関節角度が $0[\mathrm{rad}]$ に収束した. バネ引張長さが $0[\mathrm{~mm}]$ の場合においても関節角度が $0[\mathrm{rad}]$ に 収束する理由は, Fig. 12 に示すように，この状態においても関 節剛性がある值をもっているからであるとともに，CFBL の安 定性が寄与していると考えられる。

バネの引張長さが $5[\mathrm{~mm}]$ の場合は $0[\mathrm{~mm}]$ の場合に比べ, 固 有振動数が大きいことが読み取れる.これはバネ伸び量を $5[\mathrm{~mm}]$ にした場合は $0[\mathrm{~mm}]$ の場合と比較して高剛性になっているこ 


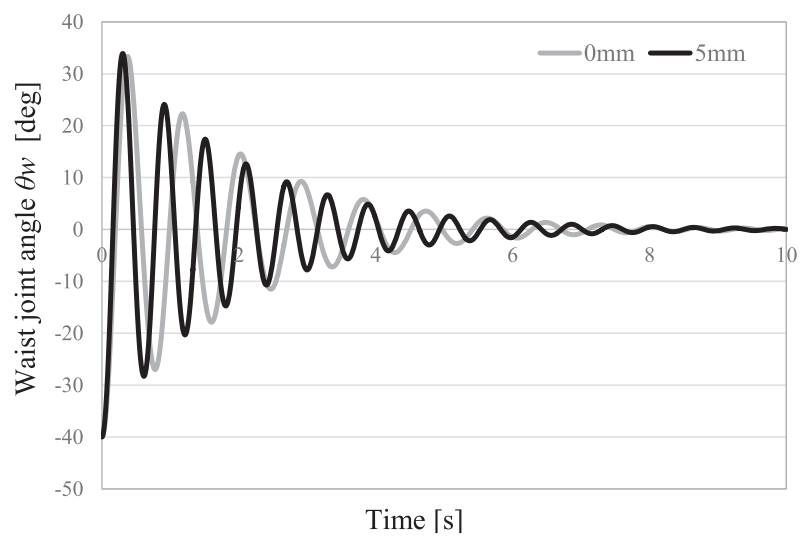

Fig. 14 Simulation results of step responses of the waist joint when spring stretch length is changed

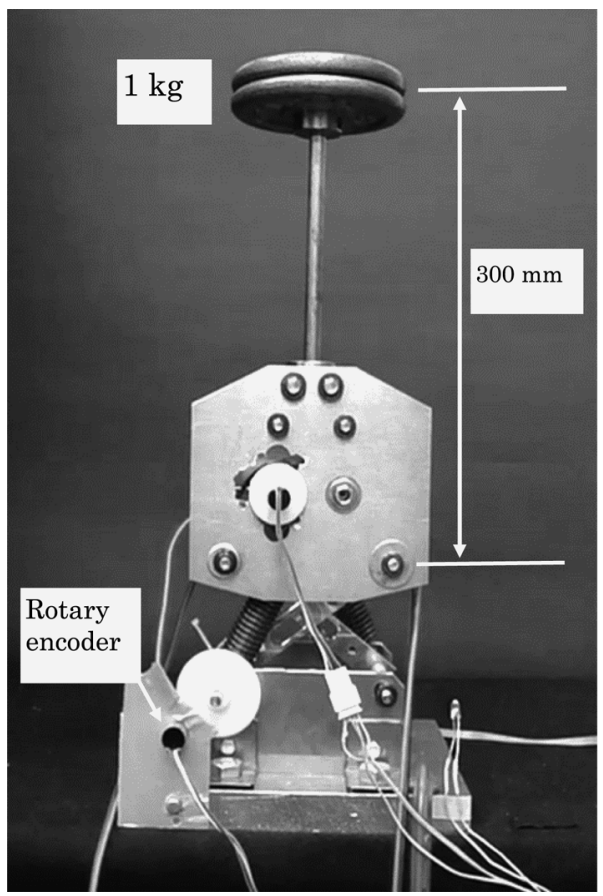

Fig. 15 Developed test machine. The detail of the links and motors allocation is seen in Fig. 1

\section{とを示している.}

\section{6. 実験機での直立安定実験と剛性調節実験}

\section{1 直立安定実験}

前述した解析モデルと解析結果を元に実験機を製作した。 Fig. 15 にその外観を示す. 諸物理量は動力学解析で用いたも のと同じである。使用したモータは Maxon 社 A-max 26（11 [W], ギアヘッド 318:1) である. Fig. 15 の p1 の位置にロータ リエンコーダを設置して関節角度 $\alpha$ （Fig. 13 参照）を測定し， その值から関節角度 $\theta_{w}$ を算出した.

実験機を用いた直立安定性実験を行い，5.2 節で述べた動力 学解析の結果を検証した. 実験条件は直立安定性解析と同様に 設定し, バネ引張長さ $0[\mathrm{~mm}]$ の状態とモータでプーリを回転 させ $5[\mathrm{~mm}]$ 伸ばした状態で行った．上体に力を加えて傾かせ，

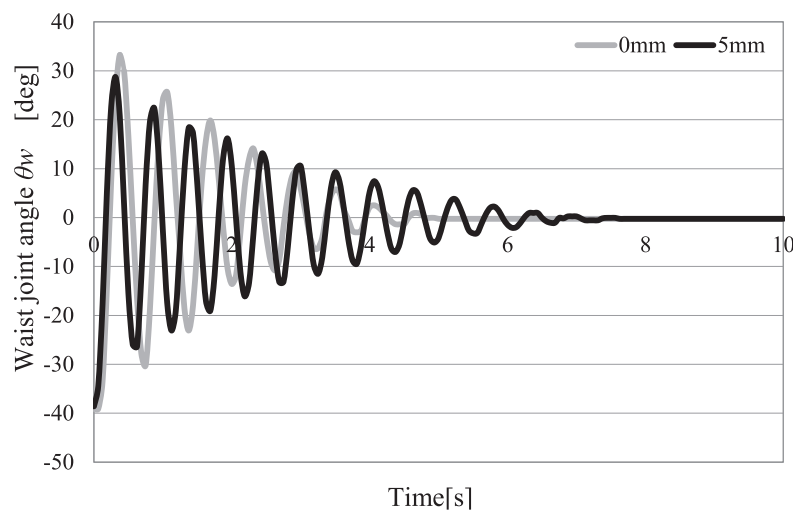

Fig. 16 Experimental results of step responses of the waist joint when spring stretch length is changed

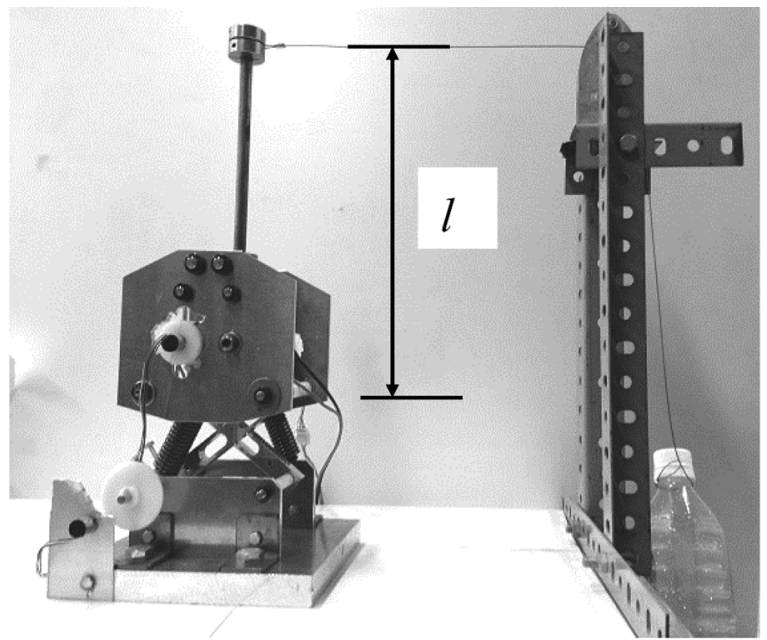

Fig. 17 The apparatus of experiments for stiffness measuring

関節角を $-40[\mathrm{deg}]$ にする. 時刻ゼロで力を開放し, 関節角度 $\theta_{w}$ の変化を計測した. 結果を Fig. 16 に示す. この結果から分 かるとおり, 動力学解析の結果と同様に両者ともに関節角度 $\theta_{w}$ が $0[\mathrm{deg}]$ に収束し, バネ引張長さが $5[\mathrm{~mm}]$ の場合は $0[\mathrm{~mm}]$ の場合と比較して固有振動数が大きいことが読み取れた. 実験 機にはロータリダンバを搭載していないため, Fig. 16 の結果に 見られる振動減衰は関節軸に存在する摩擦等の影響である.

\section{2 関節剛性の調節実験}

続いて, 第 4 章の静力学解析で理論的に設定した剛性調節範 囲を実験機を用いて検証した．関節剛性の計測方法は以下のと おりである. Fig. 17 のようにワイヤの一端を機体に固定し，も う一端にプーリを介して水平に荷重を与え，ロータリエンコー ダで計測する関節角度が $3[\mathrm{deg}]$ になるまで荷重 $\Delta m g$ を増や していき，関節剛性を以下の式で計算した。

$$
S=\Delta m g l /(3 \pi / 180) \quad[\mathrm{Nm} / \mathrm{rad}]
$$

ここで, $l$ は関節の回転中心からワイヤまでの垂直長さである. 二つのバネの引張長さをモータで $1[\mathrm{~mm}]$ ごとに増やしていき， 一つのバネ引張長さについて 5 回実験を行い，式（10）から剛 性值を算出した，その結果を Fig. 18 に示す。エラーバーは 5 回のデータのばらつき範囲を示している，この結果より, 実験 


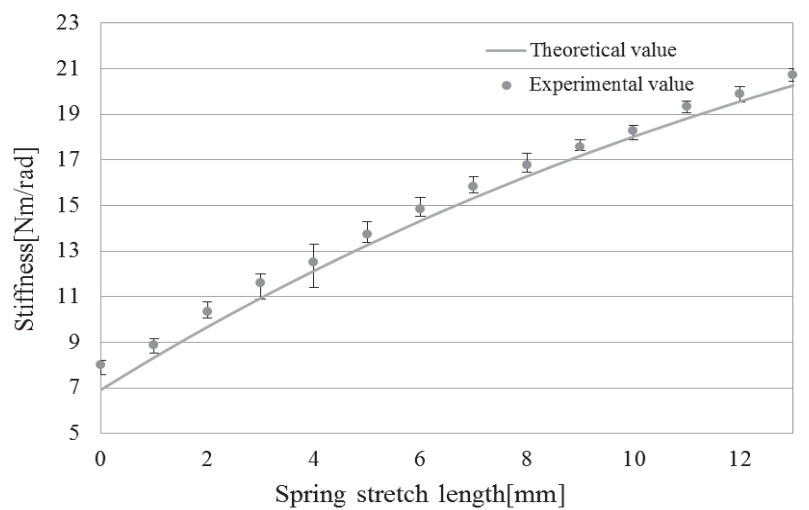

Fig. 18 Measured stiffness of the waist joint

機の関節剛性がほぼ設計どおり調節可能であることが分かる. 理論值よりも若干大きな剛性值となった理由としては, 関節や プーリに作用する摩擦の影響が考えられる。 以上から，モー夕 でバネを伸ばすことによって剛性が増加することを確認し, 初 期剛性值 $8.0[\mathrm{Nm} / \mathrm{rad}]$ に対し, 最高剛性值はバネの伸び量を $13[\mathrm{~mm}]$ に設定した場合 $20.3[\mathrm{Nm} / \mathrm{rad}]$ となった，さらに測定 值のばらつきが非常に少ないことも特筆すべきである。これは 提案した剛性調節機構において使用する弾性体がヒステリシス の少ない市販の線形バネであり，その力伝達過程においてはバッ クラッシの要因となるギアが用いられていないからである.

\section{7. 結言}

人間の歩行における腰関節や膝関節の運動は 1 周期のかなり の部分に执いて自由振動に近いが，接地や離地の瞬間に执いて 関節剛性を高め, 能動的運動が行われる. 本研究では, この人 間の下肢の筋骨格系がもつ能動／受動複合機能を模擬した交叉
型 4 リンク機構から成る腰関節機構を提案し, 静力学解析なら びに動力学解析を行ってその設計指針を明らかにするとともに， 実機を製作して実験を行い，解析結果の検証を行った。本論で 設計した機械モデルは，まずは歩行ロボットの腰関節として用 いる目的で設計されたものであるが，膝関節や足関節にも応用 が可能である，今後は，本論で提案した機構を用いた，能動／ 受動複合型 2 足歩行ロボットの開発を行っていく予定である.

\section{参 考 文 献}

[1] R. Tajima, D. Honda and K. Suga: "Fast Running Experiments Involving a Humanoid Robot," Proc. of 2009 IEEE Int. Conf. on Robotics and Autom, pp.1571-1576, 2009.

[2] T. McGeer: "Dynamics and Control of Biped Locomotion, J. of Theoretical Biology," vol.163, no.3, pp.277-314, 1993.

[ 3 ] A. Goswami, B. Thuilot and B. Espiau: "A study of the passive gait of a compass-like biped robot: symmetry and chaos, International Journal of Robotics Research," vol.17, no.12, pp.12821301, 1998.

[4] S. Collins, A. Ruina, R. Tedrake and M. Wisse: "Efficient Bipedal Robots Based on Passive-Dynamic Walkers," Science, vol.307, pp.1082-1085, 2005.

[ 5 ] M. Wisse, Daan G.E. Hobbelen and A.L. Schwab: "Adding an Upper Body to Passive Dynamic Walking Robots by Means of a Bisecting Hip Mechanism," IEEE Trans. on Robotics, vol.23, no.1, pp.112-123, 2007.

[ 6 ] 加藤, 池俣, 佐野: “上体付き受動歩行による高効率な歩行の実現”, 計 測自動制御学会, 第 12 回 SI 部門講演会（SI2011）予稿集, pp.11741175,2011

[7] K. Koganezawa, M. Takahashi and H. Ochi: "Active/Passive Hybrid Mechanism For Biped Walking," Proc. of 13th International Conference on Climbing and Walking Robots and the Support Technologies for Mobile Machines, 2010.

[8] 小金澤: “遊星歯車を用いた能動/受動融合機構”, 日本ロボット学会 誌, vol.29, no.6, pp.502-505, 2011.

[ 9 ] C.H. Suh and C.W. Radcliffe: Kinematics and Mechanisms Design. John Wiley \& Sons, 1978.

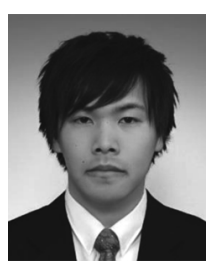

山口 懐（Natsuki Yamaguchi）

2015 年東海大学工学研究科機械工学専攻博士前期 課程修了．現在太陽工業株式会社物流システムカン パニー勤務. 修士論文研究において剛性可変機能を 有する拮抗駆動型ロボット関節の研究に従事. 修士 (工学).

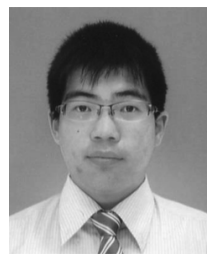

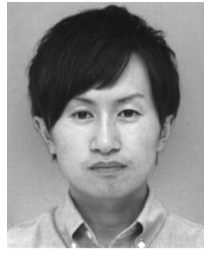

竹節淑敏（Yoshitoshi Takefushi）

2015 年東海大学工学研究科機械工学専攻博士前期 課程修了. 現在沖電気工業株式会社勤務. 修士論文 研究において剛性可変機能を有する拮抗駆動型口 ボット関節の研究に従事。修士（工学）。

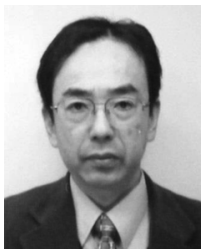

小金澤鋼一（Koichi Koganezawa）

1985 年早稲田大学大学院博士課程後期課程修了. 1987 年いわき明星大学講師, 1991 年東海大学講師, 2003 年教授，現在に至る。ロボットハンド，拮抗 型剛性可変関節, 歩行ロボット, マルチボディダイ ナミクス, 適応制御の研究に従事. 工学博士.

(日本ロボット学会正会員) 